\title{
Foreword
}

\section{Strobe Talbott}

Globalization is as old as our species. It began when early bands of Homo sapiens wandered from their home valley, crossed a mountain, and came into contact with neighbors they had not even known were there. When not massacring those they encountered-or being massacred by them-our peripatetic ancestors exchanged information and goods. Over the millennia, imperialism-from the expansive realms of the Babylonians, Egyptians, Persians, and Greeks to the Pax Romana and the Pax Britannica-was a force for what we would now call globalization.

That term, however, is new. It was coined in the 1970 os by European bureaucrats as they pondered the complex interdependencies of international trade and finance and conducted an experiment in supranational governance that is now the European Union. As the forces of globalization have accelerated over the past two decades, they have generated controversy. "Pro-globalization" pundits have bemoaned "anti-globalization" protests, as though the phenomenon were something to be for or against.

Moreover, "globalization," without a prefix, has become part of the vocabulary of the debate over the hard and soft power of the United States-and the direction of American foreign policy. Some have argued that, because of America's preponderance, "globalization" is a euphemism for "Americanization." Proponents of American unilateralism have proclaimed the United States to be the world's first "global nation," the legitimate champion of universal values, a modern-and benevolent-empire, and as such the enforcer of a Pax Americana. 
In the context of American domestic politics, globalization is equally disputatious. Workers whose manufacturing jobs have moved overseas or whose service jobs have been "outsourced," along with politicians courting their votes, have depicted the United States as a victim of globalization.

In fact, globalization is, in itself, neither a positive nor a negative phenomenon; it is a reality, a defining aspect of the modern condition. Globalization, in its technological dimension, has made instant communications possible, with all the benefits that entails for such worthy causes as bringing medical treatment to remote areas and allowing scientists on opposite ends of the Earth to collaborate in research. But just as entrepreneurs, aid workers, and good ideas can cross borders and span the globe, so can terrorists, criminals, dirty money, and disease-bearing microbes.

Therefore, what is at issue is not whether we should support or oppose globalization but how we should respond to it as a reality, how we should manage it and its consequences. It is in that spirit that Bruce Mazlish, one of the giants of intellectual and cultural history, and his fellow contributors assembled this volume. They have provided a considerable-and timely-service in helping to integrate a field of academic inquiry that has tended to be balkanized. Teachers and students of economics, political science, sociology, and other disciplines have made heroic efforts to understand globalization as it applies to their own work. But too often, as Professor Mazlish notes, those specialties had brought to bear "their own preferred set of terms, their own references, their own central foci that are very much unlike those of other disciplines in the social sciences."

What is required is more collaboration across disciplinary and institutional lines. How appropriate, then, that this book should itself be the result of a partnership between the Yale Center for the Study of Globalization and the New Global History Initiative. The emergence of those two ventures in the past decade is itself an encouraging indication of how academe is responding imaginatively to the challenge of globalization. They have both found ways to reach well beyond the academy. For example, the Yale Center is the home of the YaleGlobal online magazine, widely-indeed, globally-recognized as the best publication of its kind.

In addition to serving as catalysts for interdisciplinary inquiry and international outreach on their own campuses in New Haven and Cambridge, the Yale Center and the NGH Initiative held a joint conference in the autumn of 2003. The chapters in this book are based on papers presented at that confer- 
ence. They have since been updated and edited and now appear in print courtesy of Stanford University Press.

In keeping with the complexity of the topic, this book is a model of diversity in two respects. First, in substance, it draws from fields as diverse as history, religion, political science, and media studies. Second, while doing justice to the many important points of difference in perspective, analysis, and prescription, it brings together a variety of views and sets a high standard for civility of discourse. The result is a disciplined yet imaginative volume relevant to scholars, policymakers, and interested citizens of an increasingly globalized world. 
